\title{
Evaluation kernel fruits content of some Terminalia species cultivated in Egypt
}

\author{
Mohamed S. Abozyd, ${ }^{1}$ (D) and Hesham A. Gharib ${ }^{2^{*}}$
}

\author{
Address: \\ ${ }^{1}$ Food Technology Research Institute, Agricultural Research Center, Giza, Egypt \\ ${ }^{2}$ Horticulture Research Institute, Agricultural Research Center, Giza, Egypt \\ *Corresponding Author: Mohamed S. Abozyd, mohamedsamah72@yahoo.com
}

Received: 22.04.2021; Accepted: 10.10.2021; Published: 18.10.2021

$10.21608 /$ ejar. 2021.71523 .1102

\section{ABSTRACT}

This work evaluation kernels of Terminalia bellirica and Terminalia. arjuna covered with chocolate and applied to commercially available peanuts wrapped in chocolate, the taste and sensory qualities were assessed. T. bellirica kernels recorded a high percentage of protein and oil $(27.5 \pm 0.03$ and $34 \pm 2.00 \%)$ respectively compared to $T$. arjuna. On this concern, fatty acid composition percentage of Terminalia sp. compared to commercial olive oil. T. bellirica and T. arjuna kernels showed that higher palmitic acid content (22.58 and $21.04 \%$ ) respectively compared to olives oil, Palmitoleic acid mono-unsaturated is an omega-7 compared to T. bellirica kernels and olive oil and stearic contained (8.77 and $5.76 \%$ ) respectively compared to olives oil (2.37\%). Terminalia sp. had content omega-3 addition enhanced than olive oil of linoleic acid and omega- 6 percentage. Moreover, complete amino acids are abundant in kernels content. The most common amino acid was glutamic acid, which was followed by arginine and serine for $T$. bellirica and $T$. arjuna kernels flour content (28.8 and $23.04 \mathrm{~g} / 16 \mathrm{gN}$ ) respectively of total essential amino acids. T. arjuna kernels enhanced content $\mathrm{Ca}, \mathrm{Mg}$ and $\mathrm{K}$. T. bellirica and $T$. arjuna also contained $(0.145 \pm 0.10$ and $0.110 \pm 0.08 \mathrm{mg}),(0.351 \pm 0.01$ and $0.293 \pm 0.02 \mathrm{mg}),(0.792 \pm 0.09$ and $1.030 \pm 0.03 \mathrm{mg})$ and $(1.450 \pm 0.02$ and $0.952 \pm 0.02 \mathrm{mg})$ per $100 \mathrm{~g}$ of kernel, respectively, of vitamins B1, B2, C, and A. The results showed that Terminalia kernels coated with chocolate are more nutritious highly acceptable healthy food.

Keywords: Terminalia bellirica and Terminalia. Arjuna, kernels contents, fatty and amino acids

\section{INTRODUCTION}

Terminalia genus, Fam. Combretaceae, Angiosperms class. Terminalia is large tree, fast-growing evergreen, grown nearly $30 \mathrm{~m}$ high and the diameter is about $3 \mathrm{~m}$ and looks like a rounded crown. It is customarily buttressed trunk near the base, and branchless is more than $5 \mathrm{~m}$ long. T. bellirica classify trees as species of the genus combreta, which belongs to the Combretaceae family (Jayakumar 2019). In India, it's called "Bahera," and had used in Ayurveda (Namasivayam et al., 2021). Most developed countries still rely on tree-based nutrition and public medicine for primary care (Oeba and Illiassou 2020). Santos et al. (2016) been observed that fruit of the Terminalia has been used as a nutritional supplement or as an ingredient in food items. Akter et al. (2018) showed that T. ferdinandiana kernels were a high minerals K $6693 \mathrm{mg}, \mathrm{Ca} 5385 \mathrm{mg}$ and Fe $61 \mathrm{mg}$, as well as Zn $60 \mathrm{mg}$ were abundant added to other poor metals. On the other hand, fatty acid structure of the seed consisted of omega- 6 fatty acid, linoleic acid (50.2\%), monounsaturated oleic acid $(29.3 \%)$ and twice saturated fatty acids palmitic acid (12.0\%) and stearic acid (7.2\%). The results investigated that $T$. ferdinandiana nuts have the ability to be used in a variety of ways, it has an excellent protein source for dietary purposes and untraditional supply of linoleic and oleic as well as palmitic acids. Zhong et al. (2018) shown that $T$. cunninghamii kernels were much higher than common $\mathrm{Mg}$ and $\mathrm{Zn}$.

This study observed a lot of ability for long-period use of nuts as an excellent nutritious and stuff that is good for human health. Mojarradgandoukmolla et al. (2021) found that fed rabbits on T. arjuna showed a considerable reduction in total cholesterol and low-density lipoprotein in comparison to the control. Arjuna ksheerpaka is a milk extract used since ancient times as a public food. It possesses an excellent nutritive value. Arjuna ksheerpaka is the best acceptable for healthy individuals because it has the main important content lipids, vitamins, fatty acids, proteins, minerals and enzymes added minerals are all ingredients (Chatha et al., 2014). On this concern, yagbhatta bark of T. arjuna with milk recommended heart tonic in various cardiac problems to administer as a decoction with milk every morning in empty stomach for a long period of about a year all cardiac problems are said to be cured Tripathi et al. (1996). Ayurveda is a medicinal formula that combines the extracted seeds of $T$. bellirica known as "Triphala" had used as a nutritional and dietary supplement for a variety of health effects, including detoxification, liver safety, anti-ageing, and body rejuvenation. Ponnusankar et al. (2011) and Mukherjee et al. (2006). The main objective of the present research paper is to investigate a conventional formulation nutrition value of Terminalia in addition to estimating the taste and odder kernel of $T$. arjuna and $T$. bellirica coated with chocolate compared with peanuts. 


\section{MATERIALS AND METHODS:}

\section{Pharmacognostical studies:}

The basis of their morphology, macroscopic and microscopic characters It referred to evaluate kernel fruits of $T$. arjuna and T. bellirica by color, odor, taste, size.

Plant material:

Ripe seeds had collected in healthy condition in June of T. arjuna and T. bellirica in the 2016 season from the Giza Zoo garden and Alzohria garden, Cairo, Egypt. Seeds had rinsed with running tap water. Till all the foreign material and soil particles detached from the seed surface. Afterwards shade-dried open air at room temperature. The kernel fruits had manually separated and finely powdered by utilizing an electric grinder and separately.

\section{Phytochemical analysis:}

In this study, preliminary phytochemical screening had operated on the ethanol kernel seeds extracts according to standard methods (Chitravadivu et al., 2009). The contents of moisture, protein, crude fibres, and ash were determined using the method listed in by Horwitz (2010). Total sugar had assessed using the difference between types based on Horwitz (2010).

\section{Soxhlet extraction:}

Terminalia sp. kernels ground had placed into each thimble for soxhlet extraction. Ethanol solvent ratios had used $150 \mathrm{ml}$. This process had carried out by retching each on water glass beaker with 6 hours. The solvents were evaporated using a rotary evaporator after the time had passed.. Then the samples had collected and preserved in sealed bottles at $-20^{\circ} \mathrm{C}$ for further analysis.

\section{Oil yield calculation:}

The oil extracted by soxhlet extraction was then calculated for ethanol extraction solvent. An oil extracted was expressed as a percentage of total mass, then had formulated with the Equation below (Fauzi et al., 2011).

\section{Oil yield \% $=\frac{\text { mass of extract }(\mathrm{g})}{\text { mass of sample }(g)} \quad$ x $100 \%$}

\section{Mineral material composition:}

Material of mineral structure $\mathrm{K}, \mathrm{Mg}, \mathrm{Ca}, \mathrm{Fe}, \mathrm{Zn}$, and $\mathrm{Mn}$ of kernels of terminal spp separately powders had determined according to Horwitz (2010). Wet acid digestion was performed on the samples of kernels according to the procedure defined by Bhandari and Lucas (2018). The amounts of Fe, $\mathrm{Zn}$, and $\mathrm{Mn}$ in kernels sample that has been digested then ascertained by G.B.C. Atomic Absorption 906A by Horwitz (2010). Flame photometer 410 was used to evaluate K. Ca and Mn had Two Beam Atomic Absorption was used to determine.

\section{Determination vitamins:}

Vitamin A content using HPLC analysis between 450 and $290 \mathrm{~nm}$ lengths respectively Oliver and Palou (2000). Water extract vitamins B1 at wave 360nm addition Vitamin C and B2 have a length of $254 \mathrm{~nm}$ and $510 \mathrm{~nm}$ (Sami et al., 2014).

\section{Determinate fatty acid:}

The oil had extracted by using the analyzed method described by Kowalska et al. (2003). The fatty acid structure had described by using gas-liquid chromatography. (GLC). Benzene, methanol, and acetone were used to make methyl esters of lipids and The methylation method had obtained in one hour around $80-90^{\circ} \mathrm{C}$ using sulfuric acid 86: 10: The Apye Ubicom PU 4550 detector for dual-flame ionisation was used. An extraction for lipids methyl ester had carried out by utilizing a column of $1.5 \times 4 \mathrm{~mm}$ wrapped glass lined with cardiology 120 tangle with potted on $10 \%$ polyethylene glycol. The thermal of the oven had adapted with $8^{\circ} \mathrm{C}$. at $70^{\circ} \mathrm{C}$ to $190^{\circ} \mathrm{C}$ after that isothermal with $190^{\circ} \mathrm{C}$. The rotational speeds for hydrogen plus air became $320 \mathrm{ml} / \mathrm{min}$ of nitrogen also as gas phase at $30 \mathrm{ml} / \mathrm{min}$. The temperatures detector of injectors were $300^{\circ} \mathrm{C}$ and $250^{\circ} \mathrm{C}$, respectively. The fat chromatogram was used to determine the residence time of the uncertain fatty acids. The lipid had determined with normalizing with a component of reply analyzed utilization PU 4810 rivalry in incorporation. A lipid structure had as a proportion of the overall fat (Farag et al., 1984).

\section{Amino acid determination:}

The amino acid of Terminalia kernels $6 \mathrm{~N} \mathrm{HCl}$ was used to acid hydrolyzes the samples. The hydrolyzate had been extracted by evaporating the acid in a rotary vacuum evaporator. Proteins were measured in a protein hydrolysate using an amino acid detector, the LC 3000 amino acid scanner, a tool of LC Biochrom EPPDROP (Horwitz 2010).

Preparation of Terminalia sp. kernels covered with chocolate:

Terminalia spp. kernels were soaked in water and oven-dried after that chocolate encrusted.

\section{Sensory evaluation:}

The organoleptic characteristics of were assessed on Terminalia sp. kernels chocolate-covered peanuts vs. chocolate-coated peanut, commercial name (S \& S) according to Carpenter (2000). 


\section{Analytical statistics:}

The information had as a mean value of a standard deviation (SD) of five plicate determinations. One-way measurement of variance (ANOVA) was used to analyze the statistical study. SPSS version 17. Low significant degree at (0.05).

\section{RESULTS:}

Kernels characters:

Table (1) showed that $T$. bellirica was heavier than T. arjuna kernel, while T. arjuna and $T$. bellirica were lanceolate and spherical respectively. Odor and taste of $T$. bellirica are more agreeable than $T$. arjuna.

Table1: Some physical kernel characters of Terminalia spp.

\begin{tabular}{|l|c|c|}
\hline \multirow{2}{*}{ Characters } & \multicolumn{2}{|c|}{ Ripe Kernel fruits } \\
\cline { 2 - 3 } & T. arjuna & T. bellirica \\
\hline Color & Dark brown & Bright brown \\
\hline Odor & Mild earthy & sweet \\
\hline Taste & little acrid & medium \\
\hline Size & Small & $2-3 \mathrm{~cm}$ \\
\hline Length & $1-2 \mathrm{~cm}$ & $2-3 \mathrm{~g}$ \\
\hline weight & $1-1.5 \mathrm{~g}$ & \\
\hline
\end{tabular}

\section{Chemical Composition:}

The chemical composition of kernels. T. arjuna more moisture content than T. bellirica. Meanwhile kernels have $(20.5 \pm 0.05$ - $27.5 \pm 0.03 \%)$ protein on two terminalia sp. T. bellirica recorded higher oil percentage compared to T. arjuna. Meanwhile, $T$. bellirica and $T$. arjuna have $(2.42 \pm 0.12-2.87 \pm 0.13 \%)$ on ash respectively. On other hand, $T$. bellerica had $(6.35 \pm 0.30)$ fiber percentage as shown in Table (2).

Table 2: Chemical composition of Terminalia kernels

\begin{tabular}{|l|c|c|}
\hline Chemical component (\%) & T. arjuna & T. bellirica \\
\hline Moisture & $5.32 \pm 0.30$ & $4.85 \pm 0.28$ \\
\hline Protein & $20.5 \pm 0.05$ & $27.5 \pm 0.03$ \\
\hline Oil & $22 \pm 3.00$ & $34 \pm 2.00$ \\
\hline Ash & $2.42 \pm 0.12$ & $2.87 \pm 0.13$ \\
\hline Fiber & $3.50 \pm 0.50$ & $6.35 \pm 0.30$ \\
\hline
\end{tabular}

Fatty acid percentage of Terminalia sp.

Fatty acid compositions of Terminalia sp. kernels Figures ( 1 and 2) compared to olive oil had shown in Table (3). Palmitic a saturated acid (C16:0) percentage of $T$. bellirica and $T$. arjuna kernels recorded (22.58 and $21.04 \%$ ) respectively compared to (13.30\%) in olives oil content. Data observed T. arjuna kernels had the best contained palmitoleic acid monounsaturated is an omega7 compared to $T$. bellirica kernels and olives oil. In addition, kernels of $T$. bellirica and T. arjuna contained (8.77 and $5.76 \%)$ respectively compared to olive oil (2.37\%) of stearic saturated fatty. Oleic is a monounsaturated acid olives oil had (70.13\%) compared to T. bellirica and T. arjuna ( 28.21 and $24.35 \%$ ). Meanwhile $T$. bellirica and T. arjuna more increment than olives oil of linoleic acid percentage. On the other hand, T. bellirica and T. arjuna had omega- 6 is polyunsaturated acid compared to olives oil. Therefore, olives oil had $(0.79 \%)$ compared to T. bellirica and T. arjuna (0.16 and $0.10 \%$ ) of omega3 content.

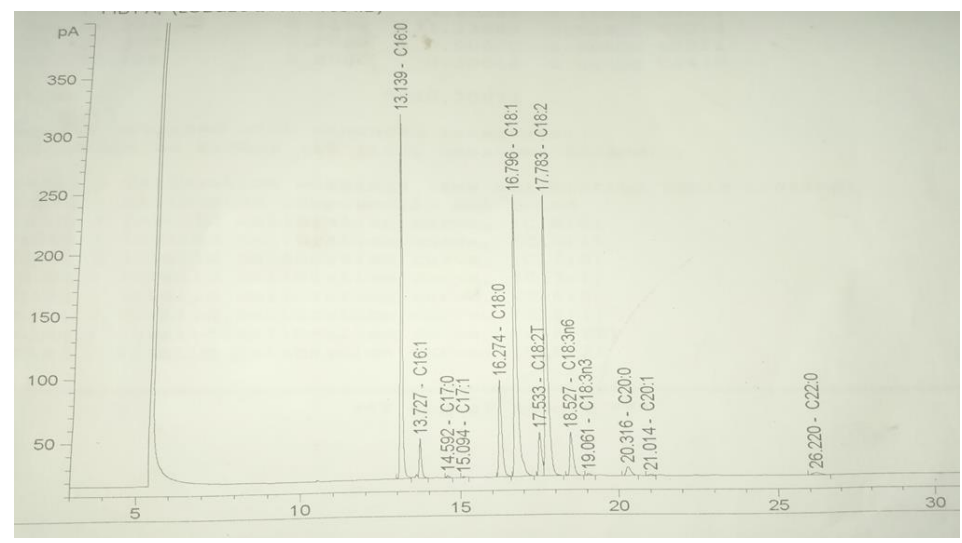

Fig. 1. T. bellirica kernels of fatty acid composition content. 


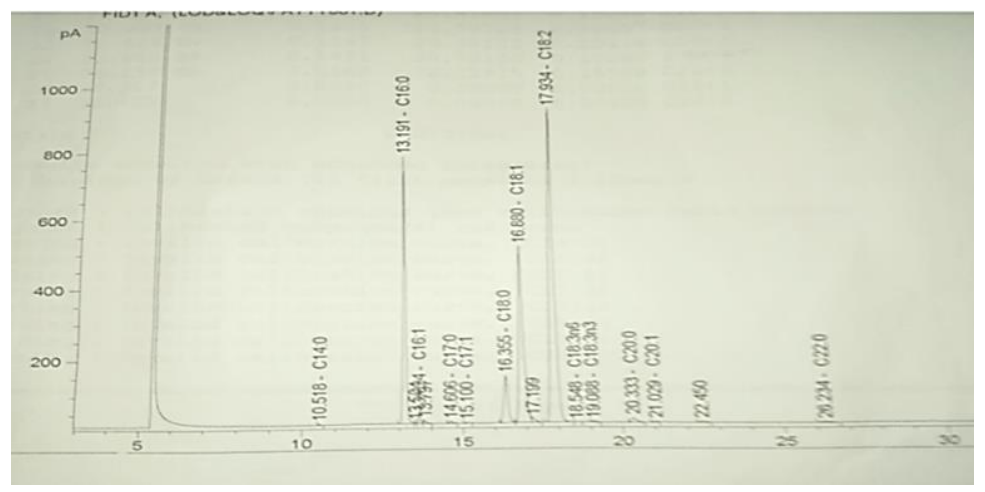

Fig. 2. T. arjuna kernels of fatty acid composition content.

Table 3: Fatty acid percentage of Terminalia sp. and marketing Egypt olive oil.

\begin{tabular}{|l|l|l|l|}
\hline Fatty acid \% & T. bellirica & T. arjuna & $\begin{array}{l}\text { olive oil } \\
\text { Bhnsawy et al. ( 2017) }\end{array}$ \\
\hline Myristic acid & - & 0.05 & 0.01 \\
\hline Palmitic acid & 22.58 & 21.04 & 13.30 \\
\hline Palmitoleic acid (C16:(1n7) omega7) & - & 0.19 & - \\
\hline Palmiololeic (zoomaric acid) (C16:1) & 2.54 & 0.56 & 0.67 \\
\hline Margaric (C17:0) & 0.15 & 0.14 & 0.05 \\
\hline Heptadecenoic acid (C17:1) & 0.06 & 0.03 & 0.1 \\
\hline Stearic (C18:0) & 8.77 & 5.76 & 2.37 \\
\hline Oleum (oleic) (C18:1) & 28.21 & 24.35 & 70.12 \\
\hline Linolelaidic acid (C18: 2T) & 3.86 & 0.47 & 0.07 \\
\hline Linoleic acid (C18:2) & 27.58 & 46.19 & 11.44 \\
\hline $\begin{array}{l}\text { Omega-6 polyunsaturated fatty acid (PUFA) } \\
\text { (C18:3 (n6)) }\end{array}$ & 4.22 & 0.30 & - \\
\hline Omega-3 & 0.16 & & \\
\hline Arachidic & 1.17 & 0.10 & 0.79 \\
\hline Eicosenoic (C20:1) & 0.16 & 0.58 & 0.46 \\
\hline Arachidonic acid (C20:4) & - & 0.10 & 0.44 \\
\hline Behenic (C22:0) & 0.53 & 0.17 & - \\
\hline
\end{tabular}

\section{Mineral Composition:}

Compositions of the elements of Terminalia kernels were described in Table (4). The inorganic mineral components of the ash in this study were $\mathrm{Mg}, \mathrm{K}$ and $\mathrm{Ca}$. T. arjuna and T. bellirica samples. Among the trace elements T. arjuna kernel more capable than $T$. bellirica.

Table 4: Mineral content of T. arjuna and T. bellirica kernels (ppm)

\begin{tabular}{|l|l|l|}
\hline Mineral & T. arjuna & T. bellirica \\
\hline $\mathrm{K}$ & $165.00 \pm 6.90$ & $156.86 \pm 0.024$ \\
\hline $\mathrm{Mg}$ & $455.32 \pm 1.60$ & $415.63 \pm 0.097$ \\
\hline $\mathrm{Ca}$ & $944.34 \pm 0.03$ & $723.51 \pm 0.010$ \\
\hline $\mathrm{Mn}$ & $9.40 \pm 0.05$ & $2.711 \pm 0.000$ \\
\hline $\mathrm{Fe}$ & $15.00 \pm 0.03$ & $3.155 \pm 0.041$ \\
\hline $\mathrm{Zn}$ & $9.00 \pm 0.05$ & $1.342 \pm 0.0013$ \\
\hline
\end{tabular}

\section{Terminalia sp. kernels amino acids content}

The structure of amino acids in Terminalia kernels flour is shown in Table (5) The most common amino acid was glutamic acid, which was followed by arginine and serine for $T$. bellirrica and $T$. arjuna respectively. Thereby, the $T$. arjuna kernel more enhanced content of $\beta$-alanine, glutamine and ornithine compare to $T$. bellirica. On the other side, $T$. bellirica and $T$. arjuna kernels flour content $(28.8$ and $23.04 \mathrm{~g} / 16 \mathrm{gN})$ respectively of total essential amino acids 
Table 5: Amino acid for T. bellirica and T. arjuna kernels composition content.

\begin{tabular}{|l|l|l|}
\hline Amino acid (g/16gN) & \multicolumn{2}{l|}{ T. bellirica } \\
\hline Non-essential amino acids & \multicolumn{2}{l|}{ T. arjuna } \\
\hline Arginine & 17.50 & 9.56 \\
\hline Alanine & 3.75 & 1.03 \\
\hline Aspartic & 7.06 & 4.22 \\
\hline Glycine & 6.22 & 2.50 \\
\hline Glutamic & 25.00 & 20.30 \\
\hline Proline & 5.26 & 10.60 \\
\hline Serine & 3.44 & 15.50 \\
\hline$\beta$-Alanine & - & 0.56 \\
\hline Glutamine & - & 4.12 \\
\hline Ornithine & - & 1.02 \\
\hline Asparagine & - & 5.32 \\
\hline Essential amino acids & \multicolumn{2}{|l|}{} \\
\hline Cystine & - & 0.32 \\
\hline Histidine & 2.42 & 2.60 \\
\hline Iso leucine & 3.46 & 3.00 \\
\hline Lysine & 3.22 & 3.50 \\
\hline Methionine & 0.72 & - \\
\hline Phenylalamine & 3.25 & 2.1 \\
\hline Tyrosine & 2.07 & 2.00 \\
\hline Threonine & 2.04 & 3.40 \\
\hline Tryptophan & 0.86 & 0.52 \\
\hline Valine & 3.81 & 2.80 \\
\hline Leucine. & 6.95 & 5.2 \\
\hline
\end{tabular}

Terminalia sp. kernels vitamin content:

The investigated data showed $T$. bellirica kernels more enhanced thiamine compared to $T$. arjuna kernels content $(0.145 \pm$ 0.10 and $0.110 \pm 0.08$ ) respectively. On this concern riboflavin kernels of $T$. bellirica increment $T$. arjuna kernels. $T$. bellirica kernels more capable than T. arjuna kernels retinol content $(1.450 \pm 0.02$ and $0.952 \pm 0.02)$ respectively. On the other hand, T. arjuna kernels recorded higher ascorbic acid content compared to $T$. bellirica kernels Table(6).

Table 6: Vitamin compositions of Terminalia sp kernels.

\begin{tabular}{|l|l|l|}
\hline \multirow{2}{*}{ Vitamin } & T. bellirica & \multicolumn{1}{l|}{ T. arjuna } \\
\cline { 2 - 3 } & Concentration $(\mathrm{mg} / 100 \mathrm{~g})$ \\
\hline Thiamine (B1) & $0.145 \pm 0.10$ & $0.110 \pm 0.08$ \\
\hline Riboflavin (B2) & $0.351 \pm 0.01$ & $0.293 \pm 0.02$ \\
\hline Retinol (A) & $1.450 \pm 0.02$ & $0.952 \pm 0.02$ \\
\hline Ascorbic Acid (C) & $0.792 \pm 0.09$ & $1.030 \pm 0.03$ \\
\hline
\end{tabular}

Sensory evaluation of terminalia sp kernels covered for chocolate:

According Table (7) the sensory test, kernels of terminalia sp. coated with chocolate prepared from T. bellirica and T. arjuna kernels were more palatable with the finest flavor and color, odder as well as over liking compared with commercial peanut chocolate named S \& S Kernels of terminalia sp. coated with chocolate had significantly enhanced taste, colour, odder and over liking acceptability.

Table 7: Sensory evaluation of terminalia sp. kernels coated with chocolate compered to peanut

\begin{tabular}{|l|l|l|l|}
\hline Character & T. bellirica & T. arjuna & Peanut seed \\
\hline Taste & $9.60 \pm 1.00 \mathrm{a}$ & $9.00 \pm 1.00 \mathrm{a}$ & $7.00 \pm 0.94 \mathrm{~b}$ \\
\hline Colour & $9.20 \pm 0.90 \mathrm{a}$ & $9.00 \pm 1.00 \mathrm{a}$ & $8.90 \pm 0.71 \mathrm{~b}$ \\
\hline Odder & $9.00 \pm 0.82 \mathrm{a}$ & $8.60 \pm 1.00 \mathrm{a}$ & $7.00 \pm 0.80 \mathrm{~b}$ \\
\hline Over liking & $9.00 \pm 0.95 \mathrm{a}$ & $8.60 \pm 1.00 \mathrm{a}$ & $7.50 \pm 0.85 \mathrm{~b}$ \\
\hline
\end{tabular}

\section{DISCUSSION}

The objective of this investigate paper spotlight the conventional formulation nutrition value furthermore evaluated taste and odder kernel fruits of T. arjuna and T. bellirica covered with chocolate compared with peanuts. On this concern, Yoganarasimhan (2000) reported that T. bellirica kernels had sweet and smell odor oil. Abraham et al. (2014) and Saraswathi et al. (2012). Further, Yoganarasimhan (2000) reported that T. arjuna fruits acrid and sweet. 
The preceding studied showed that $T$. arjuna and $T$. bellirica seed kernels contain oil, protein, and fiber. Chakradhari et al. (2019). T. bellirica kernels can currently, it's being used to food. It had the content of $40 \%$ fatty acid and $35 \%$ amino acid. Protein is a requirement It is the source of all nutrition, and life will be impossible without it. The protein rich content is essential because it exists as a source of food protein, especially for people with hypertension. Akpakpan and Akpabio (2012) recommended for kids aged 1-10, a maximum protein consumption of $0.88 \mathrm{~g} / \mathrm{kg}$ bodyweight. Das et al. (2019) investigated that terminalia sp seed with $3.95 \%$ dampness and $3.94 \%$ fiber.

Rukmini and Rao (1986) reported that oil extracted from $T$. bellirica kernels had oleic acid (24\%), palmitic acid (35\%) and linoleic (31\%) acids are the three main fatty acids content. It recommended that using oil for human diet edible consumption purposes because it considered the best source of linoleic acid. Das et al. (2019). As well as, it had observed that terminalia sp. recorded higher immersed greasy acids, particularly oleic and linoleic. Weerawatanakorn (2015) $T$. catappa kernels had oleic acid (C18:1) The major fatty acids, which accounted for $32.4 \%$. The composition of saturated, monounsaturated, and polyunsaturated fatty acids was similar to that prescribed by the Heart Association Organization nutritional recommendations. Monnet et al. (2012) investigated Palmitic acid (37.26\%) was perhaps the most concentrated fatty acid on T. catappa kernels, followed with oleic (32.40\%) and linoleic acids (24.65\%), by stearic (5.55\%), linolenic $(0.55 \%)$, palmitoleic $(0.41 \%)$, myristic $(0.17 \%)$, and lauric (trace) acids coming in second and last, respectively. On this concern The disparities in results may be attributed to a combination of genetic factors that influence lipid content. Mehran and Filsoof (1974); Canellas (1986); Amaral et al. (2006); Venkatachalam and Sathe (2006).

In addition to this data, Hasadsri et al. (2013) observed that omega-3 after brain injury in humans, it was discovered to recover neuronal functions, minimise oxidative stress, heal synaptic harm, and reduce the activation of angiogenesis processes. Patterson (2012) conclusion that unbalanced dietary consumption of converting omega-6 into omega-3 polyunsaturated effects of diet supplemented of lipids enhanced public health. Omega-3 polyunsaturated fatty acids inflammatory infections are alleviated. Garcla et al. (2017) omega-7 monounsaturated fatty acid had adjuvant decrease inflammatory.

Results agreeable as macro-and micronutrients and trace elements seed kernels' ( $\mathrm{K}, \mathrm{Mg}, \mathrm{Ca}, \mathrm{Mn}, \mathrm{Fe}$, and $\mathrm{Zn}$ ) contents ranged around (1754 - 65521 - $2150-51100-63-42300 \mathrm{mg} / \mathrm{kg}$ ) respectively. Chakradhari et al. (2019). Das et al. (2019) The seeds of terminalia sp. had evaluated $\mathrm{K}(9285 \pm 0.22 \mathrm{mg})$ was the uppermost, followed in plunging request by $\mathrm{Ca}$ $(837.20 \pm 1.28 \mathrm{mg})$ and $\mathrm{Mg}(788.68 \pm 0.21 \mathrm{mg})$. Meanwhile, Ladele et al. (2016) investigated $(100 \mathrm{~g})$ of terminalia kernel minerals contained and recommended daily intake (RDI). Who reported that $\mathrm{Mg}$ (173.6-23.52\% RDI), Fe (89.7-20.19\% RDI), Zn (87.9-12.09\% RDI) and Ca (41.5\% RDI). In the recent past Dwivedi and Udupa (1989); Zannat and Kulsum (2003) found that the $T$. arjuna contained a rich amount of $\mathrm{Mg}(4000 \mathrm{mg} / \mathrm{g})$ besides Ca $(3133 \mathrm{mg} / \mathrm{g}), \mathrm{Zn}(119 \mathrm{mg} / \mathrm{g})$ and Cu (19 mg/g).

Das et al. (2019) The seeds of terminalia sp. nutritional characters to use them for humans. Immediate examinations showed that the seed contained $24.78 \%$ protein. Weerawatanakorn (2015) noted that $T$. catappa seeds contained high levels of protein. The most limiting amino acids were tryptophan and lysine. Arginine is a source for nitric oxide, and has a variety of bioactivities including vasodilation, anti-oxidant, and anti-platelet effects, many of which have consequences for the risk of cardiovascular disease. Wells et al. (2005); Wu and Meininger (2002). Meanwhile, Venkatachalam and Sathe (2006) noted that The first restricting essential amino acids were methionine and cysteine. on nuts. Unit and World Health Organization (1992) recommended for an infant between the ages of 2 and 5.

The prior study indicated that $T$. bellirica kernels vitamin B1, B2, C, and A, respectively, formed $0.19 \mathrm{mg}, 0.45 \mathrm{mg}, 0.79 \mathrm{~g}$, and $1.1 \mathrm{mg}$. Molla et al. (2007). The previous study imdicated that terminalia contain hydroquinone, trans-cinnamic acid, genetisic trans-ferulic acid, vanillic acid Manikandan and Rejula, (2008). While cinnamic and vanillic acid used to enhance food flavor and taste Jelen (2019).

\section{CONCLUSION}

The present results revealed that kernels of terminalia sp. coated with chocolate may be put to use as food Owing to the high nutritional content, it is suitable for both youth and elderly people (protein, fat, fiber, vitamins and minerals).

\section{REFERENCES}

Abraham, A., Mathew, L., \& Samuel, S. (2014). Pharmacognostic studies of the fruits of Terminalia bellirica (Gaertn.) Roxb. Journal of Pharmacognosy and Phytochemistry, 3(2).

Ahmad, M. U., Mullah, K. B., Norin, T., \& Ulla, J. K. (1983). Terminoic acid, a new trihydroxytriterpene carboxylic acid from bark of Terminalia arjuna. Indian Journal of Chemistry Section B-Organic Chemistry Including Medicinal Chemistry, 22(8), 738-740.

Akpakpan, A. E., \& Akpabio, U. D. (2012). Evaluation of proximate composition, mineral element and anti-nutrient in almond Terminalia catappa seeds. Research Journal of Applied Sciences, 7(9-12), 489-493.

Akter, S., Netzel, M. E., Fletcher, M. T., Tinggi, U., \& Sultanbawa, Y. (2018). Chemical and nutritional composition of Terminalia ferdinandiana (kakadu plum) kernels: A Novel Nutrition Source. Foods, 7(4), 60. 
Amaral, J. S., Cunha, S. C., Santos, A., Alves, M. R., Seabra, R. M., \& Oliveira, B. P. (2006). Influence of cultivar and environmental conditions on the triacylglycerol profile of hazelnut Corylus avellana L. Journal of Agricultural and Food Chemistry, 54(2), 449-456.

Bhandari, N., \& Lucas, A. (2018). Review: techniques used in plant tissue analysis for essential elements on horticultural plants and correlate with nutrient requirement. North American Academic Research, 1, 94-113.

Bhnsawy, R., Hassanen, N., \& Eid, M. (2017). Comparative study of the quality of extra virgin olive oil in the Egyptian market (from different Mediterranean countries). International Journal of Current Science, 6(1), 208-219.

Canellas, J. (1986). Estudio de componentes quimicos de variedades de almendra de Baleares. Unpublished doctoral dissertation, Doctoral Thesis). The University of Illes Balears, Palma de Mallorca, Spain.

Carpenter, R. P., Lyon, D. H., \& Hasdell, T. A. (2000). Guidelines for sensory analysis in food product development and quality control. Springer Science \& Business Media.

Chakradhari, S., Rajhans, K. P., Patel, K. S., Towett, E. K., Martín-Gil, J., \& Martín-Ramos, P. (2019). Nutritional and spectral characteristics of Terminalia plants. European Journal of Medicinal Plants, 1-13.

Chatha, S. A. S., Hussain, A. I., Asad, R., Majeed, M., \& Aslam, N. (2014). Bioactive components and antioxidant properties of Terminalia arjuna L. extracts. Journal of Food Processing \& Technology, 5(2), 1.

Chitravadivu, C., Manian, S., \& Kalaichelvi, K. (2009). Qualitative analysis of selected medicinal plants, Tamilnadu, India. Middle East Journal of Scientific Research, 4(3), 144-146.

Das, M. P., Selvakumar S., \& Rao M. R. (2019). Nutritional characteristics of Terminalia catappa L. from seeds and oil. Plant Cell Biotchnology and Molecular Biology, 1263-1266.

Dwivedi, S., \& Udupa, N. (1989). Terminalia arjuna: pharmacognosy, phytochemistry, pharmacology and clinical use. A review. Fitoterapia, 60(5), 413-420.

Fauzi, N. A. M., Sarmidi, M. R., \& Chua, L. S. (2011). Metabolites profiling of heat treated whole palm oil extract. Journal of Applied Sciences, 11(13), 2376-2381.

Farag, R., Abdel Rahim, E. A., EL-Sharabasy, A. M., Hewedy, F., \& Ragab, A. (1984). Biochemical studies on lipids of hen's egg during incubation. Grasas y Aceites (Sevilla), 35(1), 29-34.

Garcĺa, M. D. P. M., \& YaMaMoto-FUrUsHo, J. K. (2017). Effect of Cis-palmitoleic acid supplementation on inflammation and expression of HNF4y, HNF4 $\alpha$ and IL6 in patients with ulcerative colitis. Minerva Gastroenterologica e Dietologica, 63(3), 257-63.

Hasadsri, L., Wang, B. H., Lee, J. V., Erdman, J. W., Llano, D. A., Barbey, A. K., \& Wang, H. (2013). Omega-3 fatty acids as a putative treatment for traumatic brain injury. Journal of Neurotrauma, 30(11), 897-906.

Horwitz, W. (2010). Official methods of analysis of AOAC International. Volume I, agricultural chemicals, contaminants, drugs/edited by William Horwitz. Gaithersburg (Maryland): AOAC International, 1997.

Jayakumar, K. (2019). Traditional uses of Sthalavriksham in and around Lord siva temple, Mayiladuthurai, southern India. World Scientific News, 128(2), 88-109.

Jelen, H. (Ed.). (2019). Food flavors: chemical, sensory and technological properties. CRC Press.

Kowalska, T., Kaczmarski, K., \& Prus, W. (2003). Theory and mechanism of thin-layer chromatography. In Handbook of ThinLayer Chromatography (pp. 86-129). CRC Press.

Ladele, B., Kpoviessi, S., Ahissou, H., Gbenou, J., Kpadonou-Kpoviessi, B., Mignolet, E., ... \& Moudachirou, M. (2016). Chemical composition and nutritional properties of Terminalia catappa L. oil and kernels from Benin. Comptes Rendus Chimie, 19(7), 876-883.

Manikandan, M., \& Rejula, M. (2008). Identification of allelochemicals from Terminalia chebula. African Research Review, 2(3), 306-314.

Mehran, M., \& Filsoof, M. (1974). Characteristics of Iranian almond nuts and oils. Journal of the American Oil Chemists Society, 51(10), 433-434.

Mojarradgandoukmolla, S., Nanakali, N. M. Q., \& Jabbar, A. A. (2021). Hypolipidemic and anti-oxidative activities of Terminalia arjuna barks against induced hyperlipidemic albino rats. Plant Archives, 21(1), 2082-2086.

Molla, M. T. H., Alam, M. T., \& Islam, M. A. (2007). Physico-chemical and nutritional studies of Terminalia belerica roxb. Seed oil and seed kernel. Journal of Bio-Science, 15, 117-126.

Monnet, Y. T., Gbogouri, A., Koffi, P. K. B., \& Kouamé, L. P. (2012). Chemical characterization of seeds and seed oils from mature Terminalia catappa fruits harvested in Côte d'Ivoire. International Journal of Biosciences, 10(1), 110-124.

Mukherjee, P. K., Maiti, K., Mukherjee, K., \& Houghton, P. J. (2006). Leads from Indian medicinal plants with hypoglycemic potentials. Journal of Ethnopharmacology, 106(1), 1-28.

Namasivayam, S., Venkatachalam, G., Bharani, R. S., Kumar, J. A., \& Sivasubramanian, S. (2021). Molecular intervention of colon cancer and inflammation manifestation by tannin capped biocompatible controlled sized gold nanoparticles from Terminalia bellirica: A green strategy for pharmacological drug formulation based on nanotechnology principles. 3 Biotech, 11(9), 1-20.

Oeba, V. O., \& Illiassou, S. A. (2020). Role of Tree-Based Systems in Enhancing Food Security and Nutrition. Zero Hunger, 712-723.

Oliver, J., \& Palou, A. (2000). Chromatographic determination of carotenoids in foods. Journal of Chromatography A, 881(12), 543-555

Patterson, E., Wall, R., Fitzgerald, G. F., Ross, R. P., \& Stanton, C. (2012). Health implications of high dietary omega-6 polyunsaturated fatty acids. Journal of Nutrition and Metabolism, 2012. 
Ponnusankar, S., Pandit, S., Babu, R., Bandyopadhyay, A., \& Mukherjee, P. K. (2011). Cytochrome P450 inhibitory potential of Triphala-A Rasayana from Ayurveda. Journal of Ethnopharmacology, 133(1), 120-125.

Rukmini, C., \& Rao, P. U. (1986). Chemical and nutritional studies onTerminalia bellirica Roxb. Kernel and its oil. Journal of the American Oil Chemists' Society, 63(3), 360-363.

Sami, R., Li, Y., Qi, B., Wang, S., Zhang, Q., Han, F., \& Jiang, L. (2014). HPLC analysis of water-soluble vitamins (B2, B3, B6, B12, and C) and fat-soluble vitamins (E, K, D, A, and $\beta$-carotene) of okra (Abelmoschus esculentus). Journal of Chemistry, 2014. Article ID 831357

Santos, O. V. D., Lorenzo, N. D., \& Lannes, S. C. D. S. (2016). Chemical, morphological, and thermogravimetric of Terminalia catappa Linn. Food Science and Technology, 36, 151-158.

Saraswathi Motamarri, N., Karthikeyan, M., Kannan, M., \& Rajasekar, S. (2012). Terminalia belerica Roxb.-A phytopharmacological review. International Journal of Research Pharmcology and Biomedical Science 3, 96-99.

Tripathi, V. K., Singh, B., Tripathi, R. C., Upadhyay, R. K., \& Pandey, V. B. (1996). Terminalia arjuna: Its present status (A review). Oriental Journal of Chemistry, 12, 01-16.

Unit, P., \& World Health Organization. (1992). Quality control methods for medicinal plant materials (No. WHO/PHARM/92.559/rev. 1). World Health Organization.

Venkatachalam, M., \& Sathe, S. K. (2006). Chemical composition of selected edible nut seeds. Journal of Agricultural and Food Chemistry, 54(13), 4705-4714.

Weerawatanakorn, M., Janporn, S., Ho, C. T., \& Chavasit, V. (2015). Terminalia catappa Linn seeds as a new food source. Songklanakarin Journal of Science Technology 37, 507-514.

Wells, B. J., Mainous III, A. G., \& Everett, C. J. (2005). Association between dietary arginine and C-reactive protein. Nutrition, 21(2), 125-130.

Wu, G., \& Meininger, C. J. (2002). Regulation of nitric oxide synthesis by dietary factors. Annual Review of Nutrition, 22(1), 61-86.

Yoganarasimhan, S. N. (2000). Mucuna pruriens. Medicinal Plants of India. Tamil Nadu.

Zannat, M., \& Kulsum, U. (2003). Chemical and biochemical studies on the fruit of arjun tree Terminalia arjun linn.

Zhong, L., Bornman, J. F., Wu, G., Hornoff, A., Dovi, K. A. P., Hayder, A. A., ... \& Johnson, S. K. (2018). The nutritional and phytochemical composition of the indigenous Australian pindan walnut (Terminalia cunninghamii) kernels. Plant Foods for Human Nutrition, 73(1), 40-46. 


\title{
تقيم محتوى ثمار بعض أنواع الترمناليا المنزرعة بمصر
}

\author{
1محمد سامح أبو زيد و هشام عبد السلام غريب
}

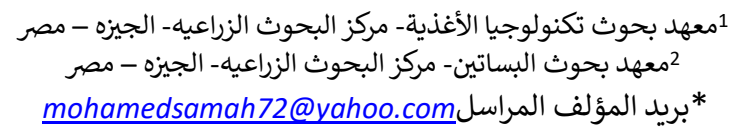

\begin{abstract}
الملخص

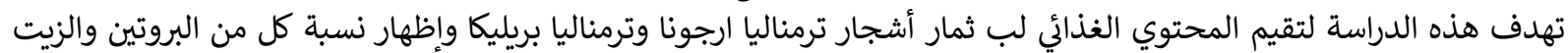

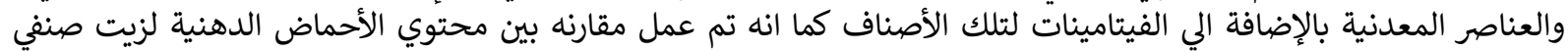

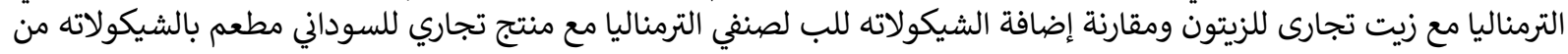

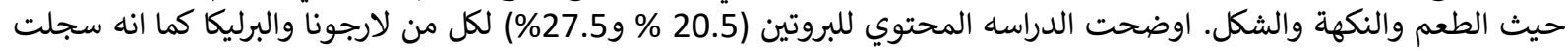

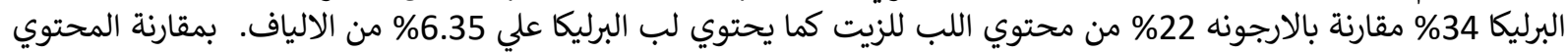

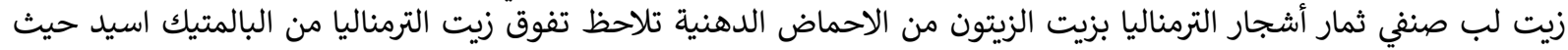

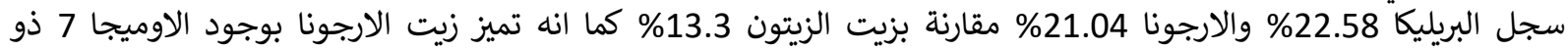

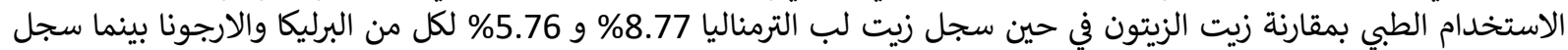

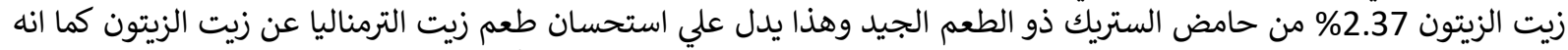

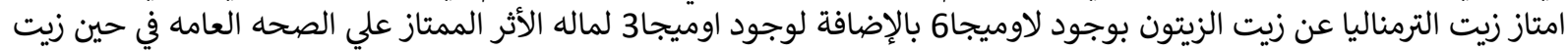

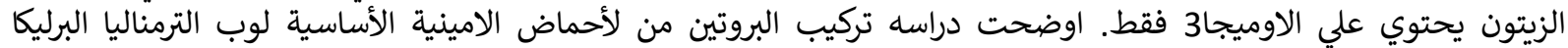

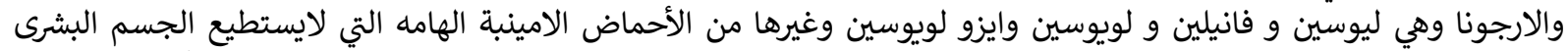

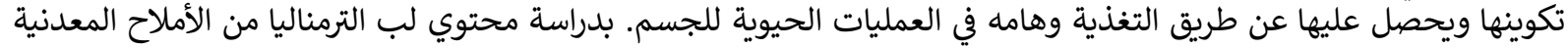

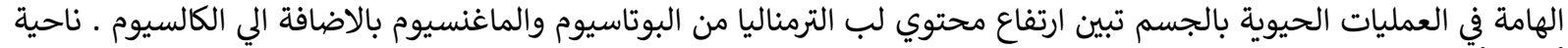

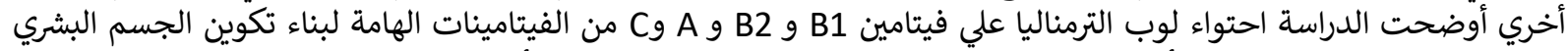

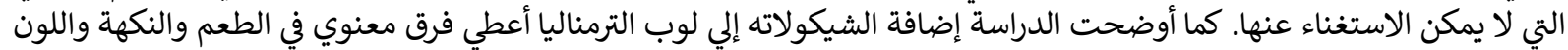

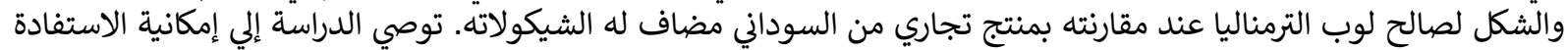

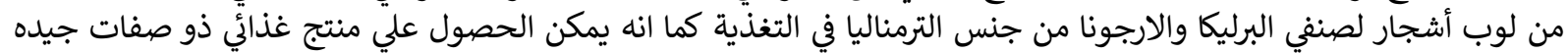

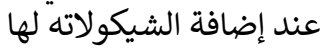
الكلمات المفتاحية: ترمناليا ارجونا وترمناليا بريليكا, محتويات الحبوب, الأحماض الدهنية والأمينية
\end{abstract}

